\title{
Applying "Management by Objectives" To the University Library
}

Many methods of library management are no longer sufficient to meet the more sophisticated demands of today. A promising management technique for librarians is "management by objectives," which helps to establish library goals, measure performance objectively, and to identify factors affecting an operation's final results.

$\mathrm{T}$ HE PROBLEMS FACING THE UNIVERSITY LIBRARY ADMINISTRATOR are becoming increasingly complex. As budgets grow tighter and the demands for library service continue to increase, the allocation of resources and the utilization of professional and nonprofessional manpower become more complex. University budget officers are demanding better justification of library expenditures with statistical analyses and facts to back up budget requests. Most academic library administrators have to plan for future needs under uncertain economic conditions and unpredictable university growth.

Librarians, like managers of other large enterprises, have come to recognize that past techniques of library management are no longer sufficient to meet the more sophisticated demands of today. Several methods of modern management have been borrowed and adapted by librarians, including a technique called "management by objectives." This concept has been defined as "a clear and precise identification of objectives or desired results, the establishment of a realistic program for their

Edward R. Johnson is assistant director for technical operations, Pennsylvania State University libraries, University Park. achievement, and an evaluation of performance in terms of measured results in attaining them."1

The Pennsylvania State University libraries have been faced with these management problems, solutions to which have been constantly sought. Recently the question arose of whether or not to continue the reclassification project in the face of dwindling monetary and manpower resources. Since the LC classification system was adopted at Penn State almost seven years ago, most of the important periodicals and serials in the collection were reclassified from Dewey in "blocks" rather than title-bytitle. The Technical Operations section was hard-pressed to maintain current activities and could no longer take on the burden of redoing large numbers of periodical and serial titles at one time. However, as the time approached for moving into a new addition to the library, it became obvious that certain remaining current periodicals and serials would have to be reclassified if the logical unity of the new building were to be maintained. Further complications developed with vacancies and the need to transfer the professional librarian and library assistant from the project to other departments.

The decision was made to continue the reclassification project, but only on 
OвJеctrve: To reclassify on a title-by-title basis, 7,186 "open" serial and periodical titles remaining in the Dewey classification and currently listed in the Serial Record within a period of two years.

\begin{tabular}{|c|c|c|}
\hline Goals & Short-Term Goals & Long-Term Goals \\
\hline $\begin{array}{l}\text { Quantitative } \\
\text { Goals }\end{array}$ & $\begin{array}{l}\text { Completion of current "block" } \\
\text { reclassification of } 3,100 \text { titles in } \\
010-019 \text { classification; } 194 \text { titles in } \\
\text { selected } 500-600 \text { classification; } 237 \\
\text { titles of selected law materials ( } 340 \mathrm{~s} \text { ). }\end{array}$ & $\begin{array}{l}\text { Completion of the reclassification, } \\
\text { title-by-title, of } 7,187 \text { titles, or } 117,968 \\
\text { volumes, of all open serial titles, } \\
\text { including } 600 \text { analyzed titles, at an } \\
\text { average rate of } 6 \text { titles per day. }\end{array}$ \\
\hline $\begin{array}{l}\text { Qualitative } \\
\text { Goals }\end{array}$ & $\begin{array}{l}\text { Completion of all cataloging, } \\
\text { classification, card and label production, } \\
\text { remarking, and card exchange by } \\
\text { nonprofessional reclassification staff } \\
\text { relatively independently and efficiently } \\
\text { with a minimum of "snags" remaining } \\
\text { after Miss -s transfer. }\end{array}$ & $\begin{array}{l}\text { Completion of the reclassification } \\
\text { project with a minimum of professional } \\
\text { direction and supervision, using only } \\
\text { available staff, and producing no } \\
\text { unusual strains on the Typing and } \\
\text { Marketing section of the Catalog } \\
\text { Department so that they can handle } \\
\text { reclassification as a part of the daily } \\
\text { routine. }\end{array}$ \\
\hline $\begin{array}{l}\text { Time } \\
\text { Period }\end{array}$ & By January 1973 & By January 1975 \\
\hline
\end{tabular}

Example 1.

Penn State's Reclassification Project

a title-by-title basis, at least until the remaining periodicals and serials could be transferred from the overcrowded old stacks into their new locations. As a different approach to the problem of reclassification was needed, it was decided to develop a working plan by applying the techniques of management by objectives. Before selecting the objective of the project, a careful analysis was made of the amount of material remaining to be reclassified, and past reclassification statistics were studied to determine performance standards. The next step was to write the objective and to chart it in terms of quantitative and qualitative goals for a given period of time (see Example 1). During this at first deceptively simple process, several objectives or variations of objectives had to be considered. Penn State's objective was checked against the following criteria developed by Morrisey:

1. It should start with the word "to," followed by an action verb.

2. It should specify a single key result to be accomplished.

3. It should specify a target date for its accomplishment.
4. It should specify maximum cost factors.

5. It should be as specific and quantitative (and hence measurable and verifiable) as possible.

6. It should specify only the "what" and "when"; it should avoid venturing into the "why" and "how."

7. It should relate directly to the accountable manager's roles and missions and to higher-level roles, missions, and objectives.

8. It should be readily understandable by those who will be contributing to its attainment.

9. It should be realistic and attainable, but still represent a significant challenge.

10. It should provide maximum payoff on the required investment in time and resources, as compared with other objectives being considered.

11. It should be consistent with the resources available or anticipated.

12. It should avoid or minimize dual accountability for achievement when joint effort is required.

13. It should be consistent with basic 
company and organizational policies and practices.

14. It should be willingly agreed to by both superior and subordinate, without undue pressure or coercion.

15. It should be recorded in writing, with a copy kept and periodically referred to by both superior and subordinate.
16. It should be communicated not only in writing, but also in faceto-face discussions between the accountable manager and those subordinates who will be contributing to its attainment. ${ }^{2}$

The next step in the management by objectives approach was to "program" the objective, by setting up the steps by which the objective was to be reached. This

Example 2.

Action Plan

Action Required

Target Date

1. Maintain reclassification as a unit in the serials department and continue current "block" reclassification plans which are closely related to the physical move soon to be undertaken.

2. Transfer Mrs. - to the monograph catalog section of the catalog department to continue her duties in transferring and withdrawing monograph snags.

3. Fill the existing professional vacancy in the serial cataloging section of the serial department so that this person can become thoroughly acquainted with the necessary procedures and routines before any personnel changes are made.

4. Establish a detailed list of priorities in close consultation with the Circulation Department so that the most needed serials are reclassified first, taking into account the problems of space availability and circulation's capacity for changes.

5. Complete the reclassification of 3,100 titles in 010-019.

6. Complete the reclassification of 194 titles in 500-600.

7. Complete the reclassification of 237 titles in law (340s).

8. Complete all remaining miscellaneous physical reclassification tasks and follow-up on "snags." Cease formal "block" reclassification.

9. Complete the remarking of all reclassified titles.

10. Upon the transfer of Miss place the direction of the Reclassification Project under one of the other experienced serial catalogers.

11. Begin the reclassification of the remaining serial titles on a title-bytitle basis, setting up a routine so that three junior catalogers can handle approximately two titles apiece per day for a total of six a day. The handling of each serial will involve:

Getting the volumes from the stacks.

Pulling the old cards, including SAF's.

Comparing copy with serial run, updating as necessary.

Assigning LC classification number and filing LC shelf list.

Preparing instruction slip for typists.

Remarking volumes.

When analytics are involved, collating all analytic cards and preparing instruction slips for each. If analytics are not available for all volumes, doing them either from LC copy or original copy. When partial analytic situations are encountered a serial cataloger will review to decide whether to pull the old analytics or do full analysis.

12. Upon completion of the remaining current serials, make a decision whether or not to bring the reclassification project, as a separate unit of the serials department, to an end.

November 1972

Mid-October 1972

Mid-November 1972

End of December 1972

January 1973

As soon as space becomes available in Pattee stacks January 1973

January 1973

January 1975 
was the "how" and was as deceptively easy to write as the "why," or the objective. The "Action Plan" for Penn State was based on careful study of the situation and in consultation with the appropriate personnel. ${ }^{3}$ Every attempt was made to consider all possibilities and to foresee all potential problems. It was determined that the current projects had to be finished first. Then, it was recommended that a set of priorities be established for the current periodicals and serials remaining to be reclassified. Past statistics indicated that a performance standard for each junior cataloger of reclassifying two titles per day was a realistic one. The plan was implemented in late September 1972. (See Example 2.)

The final step, after programming and implementation, was to assess the results. The reclassification project was almost on schedule. A significant delay in moving into the new building resulted in a lack of available space, in either the old or the new areas, for the processing and shifting of materials; only the titles in law, however, remained to be reclassified. Also, the detailed list of priorities needed completion. With the move started, the personnel in the re- classification project were in a better position to plan for the next two years, although further experience will be needed to refine the techniques and to better learn to anticipate possible problems and delays in programming and implementing objectives.

Any academic library will benefit from experimenting with the process of establishing goals. The library administration will find it useful to break down the job of management into understandable units and to place them in a logical sequence leading to a specified, and agreed upon, result. Management by objectives will facilitate the evaluation of performance as it is based on specific accomplishments within a given period of time. An "Action Plan," such as the one at Penn State, if made available for regular consultation and discussion to all levels of staff, will provide an objective, rather than a subjective, measurement of the success of a selected goal. The attainment of a specific goal might prove less important than the capacity to measure, quantitatively and qualitatively, the factors contributing to the success or failure of an operation through management by objectives.

\section{REFERENCES}

1. George L. Morrisey, Management by $\mathrm{Ob}$ jectives and Results (Reading, Mass.: Addison-Wesley Publishing Company, 1970), p. iv.
2. Ibid., p.52-60.

3. Based on an outline suggested by Dr. James Robeson, associate professor of marketing at Ohio State University. 